\title{
Prognostic Factors, Survival Analysis and Cytogenetic Outcomes in Adult Patients with Acute Myeloid Leukemia: A single Center Results
}

\author{
Hava U. TEKE ${ }^{1}$, Nur O DAVUTOGLU², Eren GUNDUZ ${ }^{1}$, Neslihan ANDIC ${ }^{1}$, \\ Cengiz BAL ${ }^{3}$, Beyhan D. ARAS ${ }^{4}$ \\ ${ }^{1}$ Eskişehir Osmangazi University, Faculty of Medicine, Department of Hematology \\ ${ }^{2}$ Eskişehir Osmangazi University, Faculty of Medicine, Department of Internal Medicine \\ ${ }^{3}$ Eskişehir Osmangazi University, Faculty of Medicine, Department of Biostatistics \\ ${ }^{4}$ Eskişehir Osmangazi University, Faculty of Medicine, Department Medical Genetics, Eskisehir, TURKEY
}

\begin{abstract}
In this study, one hundred patients under 65 years of age, who were diagnosed with acute myeloid leukemia (AML) between June 2008 to December 2015 were evaluated retrospectively. Diagnosis of the patients were based on WHO 2008 acute leukemia diagnosis criteria. One hundred AML patients were anlayzed on the basis of gender, , hemoglobin levels $<10$ and $\geq 10 \mathrm{~g} / \mathrm{dL}$ and ECOG performans status $<2$ and $\geq 2$, blast count in bone marrow $(\mathrm{BM})<\% 30$ and $\geq \% 30$, auer body presence, cytogenetics, CD56, CD19, CD2, CD7, Tdt expression, morphological types and treatment response. 52\% was male and mean age at diagnosis was $49 \pm 11.4$ (18-62) years. Response to induction therapy; complete response was 53\%, non-response was $16 \%$ and death during the induction phase was 31\%. At the end of the study analyses, 35\% of patients was in remission and $65 \%$ was dead. A multivariate Cox regression analysis revealed gender $(p=0.038, H R=0.568,95 \% \mathrm{Cl}$ : 0.332-0.97), lactate dehydrogenase $(\mathrm{LDH})$ levels $(p<0.0001, \mathrm{HR}=1.00$, 95\% Cl: 1.000-1.001), fibrinogen levels ( $\mathrm{p}=0.003, \mathrm{HR}=1.002,95 \% \mathrm{Cl}: 1.001-1.004)$, BM fibrosis $(\mathrm{p}<0.0001, \mathrm{HR}=4.098,95 \% \mathrm{Cl}$ : 2.287-7.345), cytogenetic risk classification ( $p=0.056, H R=1.486,95 \% C l: 0.990-2.231)$, fungal infection $(p=0.002, H R=0.348$, 95\% Cl: 0.179-0.677) as prognostic factors. Aberrant expression of CD2, CD7, CD19 and CD56 on AML cells were not a poor prognostic factor in this study. Gender, LDH levels, fibrinogen levels, cytogenetic risk classification, presence of fibrosis in BM and fungal infection was found to be independent risk factors on mortality in AML patients.
\end{abstract}

Keywords: Acute myeloid leukemia, cytogenetics, complete remission, prognostic factors, overall survival

ÖZET

Akut Myeloid Lösemili Erişkin Hastalarda Prognostik Faktörler, Sağkalım Analizi ve Sitogenetik Sonuçlar: Tek Merkez Sonuçları

Bu çalışmada, Haziran 2008 ile Aralık 2015 tarihleri arasında akut myeloid lösemi (AML) tanısı konulan, 65 yaş altı yüz hasta retrospektif olarak değerlendirildi. Hastalara 2008 Dünya Sağlık Örgütü (DSÖ) akut lösemi tanı kriterlerine göre akut lösemi tanıSı , hemoglobin düzeyleri $<10$ ve $\geq 10 \mathrm{~g} / \mathrm{dL}$ ve ECOG performans statüleri $<2$ ve $\geq 2$, kemik iliği blast sayısı $<\% 30$ ve $\geq \% 30$ olarak, Auer rod varlığı, sitogenetik sonuçları, CD56, CD19, CD2, CD7, Tdt ekspresyonları, morfolojik tip ve tedavi yanıtları değerlendirildi. Hastaların \%52'si erkek olup, ortalama yaşları 49+11,4 (18-62) idi. İndüksiyon kemoterapisine yanıt oranları; \%53 tam yanıt, \%16 yanıtsız, \%31 oranında indüksiyon esnasında ölüm olarak bulundu. Hastaların son durum analizinde \%35'i remisyonda olup, \%65'i ise kaybedilmiştir. Multivariate Cox regresyon analizine göre prognoz üzerine etkili faktörler; cinsiyet ( $p=0.038, H R=0.568,95 \% \mathrm{Cl}$ : 0.332-0.97), laktat dehidrogenaz $(\mathrm{LDH})$ düzeyleri $(\mathrm{p}<0.0001, \mathrm{HR}=1.00,95 \% \mathrm{Cl}: 1.000-1.001)$, fibrinjojen düzeyleri $(\mathrm{p}=0.003, \mathrm{HR}=1.002,95 \% \mathrm{Cl}$ : 1.001-1.004), kemik iliği fbrozisi ( $p<0.0001, H R=4.098,95 \% \mathrm{Cl}: 2.287-7.345)$, sitogenetik risk sınılaması $(p=0.056, H R=1.486$, 95\% Cl: 0.990-2.231) ve fungal enfeksiyon varlı̆ı̆ ( $p=0.002, \mathrm{HR}=0.348,95 \%$ Cl: 0.179-0.677) idi. CD2, CD7, CD19 ve CD56’nın aberran ekpresyonlarının prognoz üzerine etkisi bulunamadı. Cinsiyet, LDH ve fibrinojen düzeyleri, sitogenetik risk sınıflaması, kemik iliğinde fibrozis varlığı ve fungal enfeksiyon varlığı AML hastalarında mortalite üzerine etkili bağımsız risk faktörleri olarak saptandı.

Anahtar Kelimeler: Akut myeloid lösemi, Sitogenetik, Tam remisyon, Prognostik faktörler, Total yaşam süresi 


\section{INTRODUCTION}

Clinical findings and symptoms in acute myeloid leukemia (AML) are non-specific and are related to the decreased production of hematopoietic cells and invasion of other organs by the leukemic cells. ${ }^{1}$ Although no etiological factors could be detected in most of the cases, environmental factors, genetic disorders, previous history of chemotherapy, radiotherapy, and pre-existing hematologic diseases are the risk factors for AML development. ${ }^{2}$ Splenomegaly may occure as frequent as $50 \%$ in the AML patients, but lymphadenopathy is rare. According to the 2008 World Health Organization (WHO) the patient is diagnosed with acute myeloid leukemia if the blastic cell count in the bone marrow is more than $20 \%$. In order to make a differential diagnosis of leukemia type and its subgroups, morphologic and immunohistochemical evaluations, cytogenetic analyses and flowcytometric evaluation must be performed. ${ }^{3}$

Variables that enable us to predict the course of the disease and response to treatment are called prognostic factors. Prognostic factors can be classified into two categories, namely, those that are related to the patient's overall health and those that are related to the biological properties of the leukemia. Advanced age ( $>60)$, comorbid diseases, secondary AML, existing dysplasia, absence of Auer rods, subtypes M0, M5, M6, and M7, CD34 expression, CD56 expression, extramedullary disease, fibrosis in bone marrow, slow response to cytoreduction, administration of multiple chemotherapy sessions to obtain a full response, presence of Philadelphia $(\mathrm{Ph})$ chromosome, monosomy in 5th and 7th chromosomes, complex karyotypes, and presence of FMS-like tyrosine kinase (FLT3) are associated with poor prognosis, whereas presence of Auer rods, M3 and M4Eo subtypes (based on FranceAmerica-Britain classification), $\mathrm{t}(8 ; 21), \mathrm{t}(15 ; 17)$, inversion (inv) $16, \mathrm{t}(16 ; 16)$ presence, and presence of nucleophosmin-1 (NPM1) and CCAAT/enhancer binding protein alpha (CEBPA) are associated with good prognosis. ${ }^{4,5}$ Risk of infection in AML patients depends on the degree of neutropenia. Intravenous vein access and mucositis increase systemic bacterial translocation. Most frequently isolated bacteria in patients with febrile neutropenia (FEN) are gram negative aerobs such as Klebsiella,
Pseudomonas, and E.coli and gram positive organisms such as Streptococcus viridans and Staphylococcus spp. [4]. Presence of invasive aspergillosis (IA) in AML patients worsens the prognosis. After the induction chemotherapy, regardless of the patients remission status, presence of IA increases the risk of mortality. ${ }^{6}$

The aim of our study is to detect the clinical and laboratory characteristics of our AML patients as well as the factors that affect the prognosis, to compare the results with the existing literature and to identify any regional differences.

\section{MATERIALS AND METHODS}

\section{Patients}

In this study, 100 patients under 65 years of age who were diagnosed as AML based on WHO 2008 acute leukemia diagnosis criteria in Eskişehir Osmangazi University Faculty of Medicine, Department of Internal Medicine, Hematology division from June 2008 to December 2015 were evaluated retrospectively. They were prospectively followed up until November 2016. Eleven AML patients who did not take " $7+3$ " or "all-trans retinoic acid (ATRA) + anthracycline' remission induction chemotherapy were excluded from the study.

Complete blood count, C-reactive protein, erythrocyte sedimentation rate, PT-aPTT-INR, fibrinogen, D-dimer, biochemical tests such as uric acid and LDH, karyotype analysis, FLT-3, NPM1, t(15;17), $\mathrm{t}(8 ; 21)$, inv(16) results were evaluated as laboratory parameters. Time period between diagnosis and induction, whether or not the patient received maintenance treatment and if so, type of maintenance treatment patients have received, responsiveness to induction chemotherapy, number of consolidation chemotherapy cycles the patients received, time of recurrence, whether or not allogeneic bone marrow transplantation was performed, overall survival, and disease-free survival were evaluated. Percentage of blastic cells in the bone marrow aspiration, presence of Auer body, flowcytometry results of bone marrow aspirate, presence of fibrosis and dysplasia in bone marrow biopsy were analyzed. Presence of hepatomegaly, splenomegaly, and lymphadenopathy in imaging 
Table 1. Charateristic of patients with AML

\begin{tabular}{|c|c|}
\hline Characteristic & $\begin{array}{l}\text { All patients } \\
(n=100)\end{array}$ \\
\hline Median age (range), years & $49(18-62)$ \\
\hline \multicolumn{2}{|l|}{ Gender } \\
\hline Female & 48 \\
\hline Male & 52 \\
\hline \multicolumn{2}{|l|}{ Cytogenetic group } \\
\hline $\mathrm{t}(8 ; 21)$ & 3 \\
\hline $\operatorname{inv}(16)$ & 6 \\
\hline $\mathrm{t}(15 ; 17)$ & 17 \\
\hline Normal karyotype & 36 \\
\hline Other & 38 \\
\hline \multicolumn{2}{|l|}{ FAB classification } \\
\hline MO & 14 \\
\hline M1 & 18 \\
\hline M2 & 21 \\
\hline M3 & 17 \\
\hline M4 & 24 \\
\hline M5 & 5 \\
\hline M6 & 1 \\
\hline M7 & 0 \\
\hline \multicolumn{2}{|l|}{ ECOG performance score } \\
\hline 0 & 64 \\
\hline 1 & 31 \\
\hline 2 & 4 \\
\hline 3 & 1 \\
\hline 4 & 0 \\
\hline \multicolumn{2}{|l|}{ WBC count at diagnosis } \\
\hline$<30000 / \mathrm{mm}^{3}$ & 60 \\
\hline$\geq 30000 / \mathrm{mm}^{3}$ & 40 \\
\hline \multicolumn{2}{|c|}{ Response to induction chemotherapy } \\
\hline Complete remission & 53 \\
\hline Unresponsive & 16 \\
\hline Death during induction & 31 \\
\hline
\end{tabular}

studies were evaluated. Presence of fever $>38^{\circ} \mathrm{C}$, DIC, hemorrhage, and thrombosis at the time of diagnosis were evaluated. Febrile neutropenia episodes, microorganisms isolated in blood, urea and sputum cultures, mucositis, catheter infection, typhlitis, rectal abscess and the adverse effects of chemotherapy were investigated. Presence and type of invasive fungal infection (IFI) and type of chemotherapy at the time of IFI and presence of antifungal proflaxis were recorded.

\section{Statistical Analysis}

Analyses were performed using IBM SPSS Statistics 21.0 (IBM Corp. Released 2012. IBM SPSS
Statistics for Windows, Version 21.0. Armonk, NY: IBM Corp.) program. Confidence interval was set to $95 \%$ and $\mathrm{p}<0.05$ was considered statistically significant. Chi-square test was used to analyze the crosstables. Kaplan-Meier test was used to draw the survival curve when comparing survival time of the groups. Log-rank test was used in the evaluation of differences between groups. Univariate and multivariate stepwise cox-regression was used to identify prognostic variables that affect survival time. Data were presented as mean $\pm \mathrm{SD}$ (standard deviation).

\section{RESULTS}

\section{Overall Results}

One hundred patients were included in the study. Anthracycline-cytarabine $7+3$ was applied in AML (non-APL) patients as the induction chemotherapy protocol and received 2-4 high-dose cytarabine courses for consolidation. Idarubicin and ATRA was applied in acute pro-myelocytic leukemia (APL) patients as the induction chemotherapy. Three ATRA-anthracycline consolidation courses followed by ATRA-methotrexate-6-mercaptopurine maintenance for 2 years were used in APL patients.

The median follow-up time was 200 days (range 3-1666). Of our cases, 52 (52\%) were male, 48 (48\%) were female. Mean age of the patients at the time of diagnosis was $49 \pm 11.4$ (18-62) years. Place of residence was city centers in 76 , and villages in 24 patients. In terms of comorbid diseases, 4 patients $(4 \%)$ had coronary artery disease, 13 patients $(13 \%)$ had hypertension, 17 patients $(17 \%)$ had diabetes mellitus, 8 patients $(8 \%)$ had chronic obstructive pulmonary disease, and 1 patient (1\%) had chronic renal failure.

Bone pain was detected in 68 patients $(68 \%)$. ECOG performance status score was $\leq 1$ in 95 patients $(95 \%)$. The main baseline characteristics of patients are presented in Table 1. When the patients were evaluated in terms of hemorrhage at the time of admittance, it was found that 40 patients (40\%) had hemorrhagic symptoms; petechiae and purpura. DIC was noted in 20 patients (20\%) at the time of diagnosis. 
International Journal of Hematology and Oncology

\begin{tabular}{|c|c|}
\hline Abnormal karyotypes analysis results, $n=21$ & FISH analysis results, $n=16$ \\
\hline $46, X X, t(15 ; 17)(q 22 ; q 11)[20]$ & $\mathrm{t}(8 ; 21) 97,1 \%(+)$ \\
\hline $46, X X, t(9 ; 22)(q 34 ; q 11)[16] / 46, X X[2]$ & MLL 43,85\% Trisomy 11 (+), 35,96 \% Tetrasomy (+) \\
\hline $47, X Y,+8[14] / 46, X Y[1]$ & MLL 96,15\% translocation (+) \\
\hline $47, X Y,+21[2] / 46, X Y[18]$ & $\mathrm{t}(15 ; 1790 \%(+)$ \\
\hline Complex karyotype $43-46$ chromosome & $\mathrm{t}(15 ; 17) 95,98 \%(+)$ \\
\hline $47, X X,+8[6] / 46, X X[2]$ & $36,58 \% 5 q$ deletion $(+)$ \\
\hline 46,XX,inv(16)(p13q22)[12]/46,XX[4] & 83,17 \% Monosmy $7(+)$ \\
\hline 46,XY,inv(16)(p13q22)[5]/46,XY[2] & $\operatorname{inv}(16) 65,72 \%(+)$ \\
\hline $47, X Y,+11[21]$ & $\operatorname{inv}(16) 72,13 \%(+)$ \\
\hline $46, X X, t(15 ; 17)(q 22 ; q 11)[15]$ & $\mathrm{t}(15 ; 17) 93,33 \%(+)$ \\
\hline $46, X X, t(15 ; 17)(q 22 ; q 11)[17] / 46, X X[3]$ & $\mathrm{t}(9 ; 22) 94,01 \%(+)$ \\
\hline 46,XY,der(12)[7]/46,sl,-7,+mar[2]/48,XY,+2, mar[1] & $\mathrm{t}(8 ; 21) 70 \%(+)$ \\
\hline $45, X Y,-7[15]$ & 95,04 \% Trisomy 8 (+) \\
\hline $47, \mathrm{XY},+11[10] / 47, \mathrm{XY},+\mathrm{i}(11)(\mathrm{q} 10))[6] / 46, \mathrm{XY}[2]$ & 9 \% Trisomy $21(+)$ \\
\hline $45, X X, \operatorname{der}(11),-19[3] / 42, s l,-8,-10,19[3] / 46, X X[1]$ & 48,33 \% AML1 deletion \\
\hline $45, X,-X[5] / 46, X X[2]$ & 46,80 \% Trisomy 8 (+) \\
\hline $47, X X,+8[1] / 46 X X[10]$ & PCR analysis results \\
\hline \multicolumn{2}{|l|}{$46, X Y, t(15 ; 17)(q 22 ; q 11)[10]$} \\
\hline 46,XY,del(6)(p22)[6]/46,XY[14] & $\mathrm{t}(15 ; 17)$ positivity, $\mathrm{n}=17$ \\
\hline $45, X X, t(2 ; 3)(q 37 ; p 22),-12[10]$ & $\mathrm{t}(8 ; 21)$ positivity, $\mathrm{n}=3$ \\
\hline \multirow[t]{3}{*}{$47, X X,+9, \operatorname{der}(21)[15]$} & inv(16) positivity, $n=6$ \\
\hline & NPM1 positivity, $n=22$ \\
\hline & FLT3-ITD positivity, $n=8$ \\
\hline
\end{tabular}

Hepatomegaly was present in 33 patients (33\%), splenomegaly was present in 26 patients $(26 \%)$, and lymphadenopathy was present in 25 patients $(25 \%)$. The number of patients with fever $\left(>38.0^{\circ} \mathrm{C}\right)$ at the time of first admittance was 36 $(36 \%)$.

Mean hemoglobin value of the patients at the time of admittance was 9.2 $\pm 2.1 \mathrm{~g} / \mathrm{dL}$ (3600-631.000), LDH value was $1291 \pm 1159 \mathrm{U} / \mathrm{L}(68-6430)$, uric acid value was $5.8 \pm 2.3 \mathrm{mg} / \mathrm{dL}$ (1.32-18.8).

At the time of diagnosis, bone marrow blast level was $56.69 \% \pm 20.6$ (21-93). In bone marrow aspiration examinations, 20 of 100 patients $(20 \%)$ had Auer body. Bone marrow biopsy examinations revealed that 17 of 100 patients (17\%) had dysplasia, and 49 patients (49\%) had fibrosis.

According to WHO 2008 classification, 26 of our AML cases had recurrent genetic abnormalities.
Among them, 3 had $t(8 ; 21)(+), 6$ had inv(16) (+), 17 had $\mathrm{t}(15 ; 17)(+)$. Not otherwise specified 68 AML patients were further classified as 12 patients with minimal differentiation, 15 patients without maturation, 14 patients with granulocytic maturation, 16 patients with acute myelomonocytic leukemia, 5 patients with acute monoblastic/monocytic leukemia, and 2 patients had panmyelosis with myelofibrosis. Moreover, 3 patients were cathegorised as AML with myelodysplasia-related changes and 3 other as cases of therapy-related myeloid neoplasm.

AML disease in 92 patients was of primary type, while 8 had secondary AML. AMLs had developed secondary to myelodysplastic syndrome in 3 cases, to myelofibrosis in 2 cases. One patient had Hodgkin lymphoma, one had anaplastic lymphoma, and one had testicular carcinoma before the diagnosis of AML. 


\section{Cytogenetic and Molecular Analysis}

In cytogenetic examinations, karyotype analyses of 57 patients were available; 36 of which were normal karyotypes whereas 21 were abnormal karyotypes. FLT-3-ITD mutation (+) was detected in 8 patients $(8 \%)$, and NPM1 mutation $(+)$ was detected in 22 patients (22\%). The abnormal karyotype, positive FISH analysis and PCR results are presented in Table 2.

Among 96 patients whose detailed results were available after the classification of the patients in terms of cytogenetics and molecular genetics, 35 patients were in favorable cytogenetic risk group, 47 were in intermediate cytogenetic risk group and 14 were in poor cytogenetic risk group.

\section{Febrile Neutropenia and Invasive Fungal Infection}

Febrile neutropenia was reported in 84 patients (84\%). The most frequently isolated organisms from 57 patients with growth in the blood culture were Acinetobacter baumannii, Staphylococcus spp, and Escherichia coli. The most frequently isolated organisms from 25 patients with growth in the urine culture were Escherichia coli and Candida albicans. The most frequently isolated organisms from 21 patients with growth in the sputum culture were Acinetobacter baumannii, Stenetrophomonas maltophilia, and Pseudomonas aeruginosa.

Posaconazole was prescribed to 77 patients (77\%) as a prophylactic antifungal treatment. Fungal infection was detected in 69 of 100 patients, 61 of whom had fungal pneumonia, 5 had fungal pneumonia and paranasal fungal infection, 1 had paranasal fungal infection, 2 had fungal pneumonia and hepatosplenic candidiasis. In high resolution computer tomography of 67 patients, symptoms compatible with fungal pneumonia were detected. 49 (71\%) of 69 patients diagnosed with fungal infection, fungal infection occured at the time of induction chemotherapy.

\section{Treatment and Complications}

Induction chemotherapy was given to the patients after a median of 9 days (1-38) following the diagnosis. Mucositis developed in 68 patients $(68 \%)$, typhlitis developed in 8 patients $(8 \%)$ and rectal abscess developed in 10 patients (10\%). Cathether was inderted in 38 patients (38\%). Chemot herapyrelated adverse effects were found in 26 patients (26\%). One patient had tumour lysis syndrome, 1 had hypokalemia due to severe diarrhea, 1 had neuropathy, 2 had Fournier's gangrene, 5 had drugrelated vasculitis, 2 had acute renal failure, 5 had ATRA syndrome, 2 had hepatotoxicity, 9 had ileus, 1 had deep venous thrombosis, 1 had hyperbilirubinemia, and 1 had autotoxicity.

\section{Immunophenotyping}

There was no difference between CD56 positive and negative group regarding $\mathrm{CD} 34$ and $\mathrm{CD} 7$ positivitiy, cytogenetic risk groups and complete remission ratio after first induction therapy ( $\mathrm{p}>$ $0.05)$. Mean overall survival of CD56(+) patients were $381 \pm 143$ days whereas mean overall survival of CD56 negative patients were $182 \pm 46.2$ days, but the difference did not reach statistical signifigance ( $p>0.05$ ). Cytogenetic risk groups were not different between CD 7 positive and negative patients ( $>$ 0.05).

Patients positive for the aberrant marker CD 19 were not diferent from negative ones in terms of overall survival and disease free survival ( $p>0.05$ ). Disease-free survival in patients negative for the aberrant marker Tdt was $574.975 \pm 77.4$ days, mean disease-free survival time in 4 patients positive for Tdt was $188 \pm 11.8$ days and all tdt + patients deceased. Bu this difference was not statistically significant ( $p>0.05)$. In terms of overall survival, Tdt(-) group survived 624.466 \pm 77.9 days, Tdt(+) group survived 255.250 \pm 131.4 days and no significant difference was detected ( $>0.05)$. Aberrant marker CD2 was detected in only one patient and the overall survival of the patient was 17 days.

\section{Prognostic Factors and Survival}

Mean overall survival of the patients was 203.0 74.6 (0-1666) days, disease-free survival was $137.0 \pm 46.7(0-1588)$ days. Patient response to induction chemotherapy was as follows: $53 \%$ $(n=53)$ complete response, $16 \%(n=16)$ unresponsive, $31 \%(n=31)$ death during induction. Fifty- 
Table 3. Responsiveness of cases to induction chemotherapy, fibrosis in bone marrow, presence of Auer body and blast amount, cytogenetic risk group, presence of invasive fungal infection and their effects on overall survival.

\begin{tabular}{|c|c|c|c|}
\hline Parameter & Patients $n=100$ & $\begin{array}{l}\text { Overall survival, (mean } \pm \text { standard } \\
\text { deviation)/day }\end{array}$ & $p$ value \\
\hline \multicolumn{4}{|c|}{$\begin{array}{l}\text { Complete remission after the first induction } \\
\text { chemotherapy }\end{array}$} \\
\hline Presence & $53(53 \%)$ & $1052,7 \pm 102,5$ & $<0.0001$ \\
\hline Absent & $47(47 \%)$ & $66,8 \pm 14,6$ & \\
\hline \multicolumn{4}{|l|}{ Bone marrow fibrosis } \\
\hline Presence & $49(49 \%)$ & $308,4 \pm 71,3$ & $<0.0001$ \\
\hline Absent & $51(51 \%)$ & $862,07 \pm 112,9$ & \\
\hline \multicolumn{4}{|l|}{ Bone marrow auerbody } \\
\hline Presence & 20(20\%) & $1075,7 \pm 168,2$ & 0.005 \\
\hline Absent & $80(80 \%)$ & $473,6 \pm 76,4$ & \\
\hline Cytogenetic risk classification & $\mathrm{n}=96$ & & \\
\hline Favorable & $35(36 \%)$ & $982,9 \pm 133,6$ & 0.016 \\
\hline Intermediate & $47(49 \%)$ & $410,7 \pm 83,6$ & \\
\hline Poor & $14(15 \%)$ & $414,1 \pm 150,6$ & \\
\hline \multicolumn{4}{|l|}{ Invasive fungal infection } \\
\hline Presence & 69(\%69) & $578,6 \pm 86,5$ & 0.538 \\
\hline Absent & $31(\% 31)$ & $648,9 \pm 140$ & \\
\hline \multicolumn{4}{|l|}{ Bone marrow blast ratio } \\
\hline$<\% 30$ & 10(\%10) & $330 \pm 137$ & 0.808 \\
\hline$\geq \% 30$ & $90(\% 90)$ & $200 \pm 91,7$ & \\
\hline
\end{tabular}

five patients received consolidation chemotherapy. Among the patients who completely responded to induction chemotherapy, $15(28 \%)$ had recurrence. In the total cohort of 100 patients, $20(20 \%)$ had allogeneic stem cell transplantation; 17 after 1 st complete remission, and 3 after 2 nd complete remission. Seven recipients of allogeneic stem cell transplant had graft versus host disease. At the end of the follow up period, $35 \%$ of the patients $(n=35)$ were in remission and $65 \%$ of the patients $(n=65)$ were deceased .

Patients were classified into various groups, that is, according to their leukocyte count as, $\mathrm{Hb}<10$ and $\geq 10 \mathrm{~g} / \mathrm{dL}$ and ECOG $<2$ and $\geq 2$, blast count in bone marrow as $<\% 30$ and $\geq \% 30$, and no statistically significant differences were found regarding complete response, overall survival and diseasefree survival among these groups ( $\mathrm{p}>0.05)$.

Patients who completely responded to induction chemotherapy, who had no fibrosis in bone marrow biopsy, who had Auer body in their bone marrow aspirations, and who were classified into good cytogenetic risk had statistically significantly longer overall survival $(\mathrm{p}<0.0001, \mathrm{p}<0.0001, \mathrm{p}<0.0001$, and $p=0.005$, respectively) (Table 3 , Figure 1 ).

Patients who completely responded to induction chemotherapy, who had no fibrosis in bone marrow biopsy, who had auer body in their bone marrow aspirations, and who were classified into good cytogenetic risk had statistically significantly longer disease free survival $(\mathrm{p}<0.001, \mathrm{p}<0.001, \mathrm{p}=$ 0.005 , and $\mathrm{p}=0.016$, respectively).

No statistically significant difference was detected in overall survival between the patients with and without invasive fungal infection ( $p>0.05$ ).

When patients were classified into two groups according to their leukocyte count being was statistically significantly longer $(\mathrm{p}=0.012)$.

Rebound thrombocytosis (RT) (plt $\geq 450000 /$ $\mathrm{mm}^{3}$ ) were detected in 15 of 53 patients who at- 

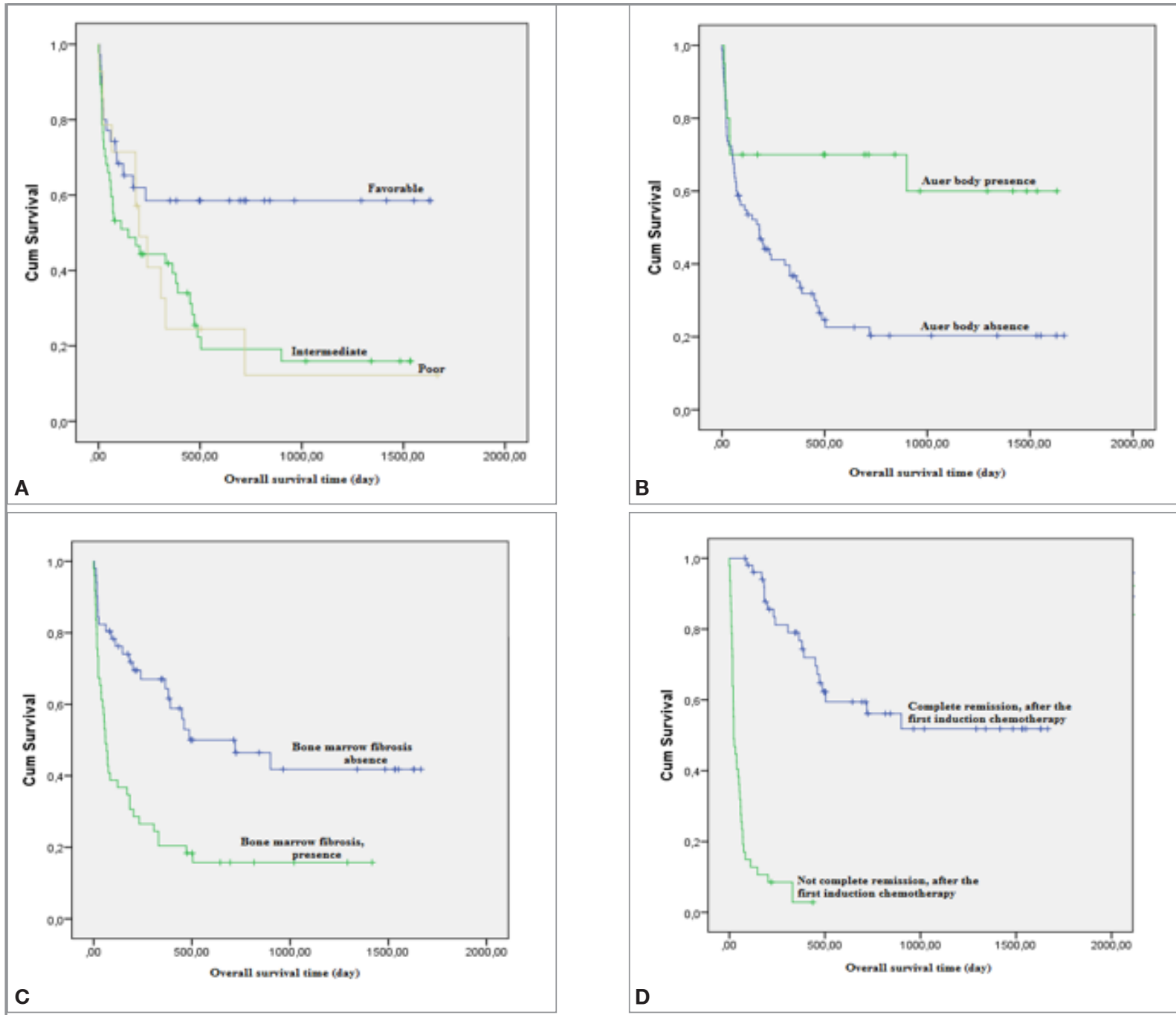

Figure 1. Overall survival curves of the AML patients based on (A) Cytogenetic risk classification, (B) Presence of Auer body, (C) Presence of fibrosis in bone marrow, (D) Response to induction chemotherapy

tained the complete remission (CR) after induction chemotherapy. The mean platelet count was $617000 \pm 151679 / \mathrm{mm}^{3}(455000-967000)$ in RT groups and $268763 \pm 94247 / \mathrm{mm}^{3}(105000 \pm 418000)$ in non-RT groups. OS, ECOG performance status, cytogenetic risk classification, age, gender and leukemia type were not statistifically significant between RT and non-RT groups in univariate analyses $(p>0.05)$.

When the causes of mortality of the 65 patients who died were investigated, most frequent causes were as follows: fungal pneumonia in 10 patients (15\%), fungal pneumonia and sepsis in 22 patients (33.84\%), cerebrovascular events in 13 patients $(20 \%)$.
Stepwise cox regression analysis revealed that gender, LDH, fibrinogen cytogenetic risk classification, presence of fibrosis in bone marrow, and presence of fungal infection were the factors that were found to affect mortality (Table 4).

\section{DISCUSSION}

Prognostic factors in malignant diseases are related to multiple negative or positive outcome parameters. In AML, there is a correlation between complete response rate following the induction treatment and overall survival, and also, between disease-free survival and the factors that affect the success of complete response as well as the fac- 
Table 4. Univariate and multivariate analysis on overall survival in AML patients

\begin{tabular}{lllll}
\hline & \multicolumn{2}{c}{ Univariate analysis } & \multicolumn{2}{l}{ Multivariate analysis } \\
\cline { 2 - 5 } Clinical/biological variable & Hazard ratio (95\% Cl) & p value & Hazard ratio (95\% Cl) & p value \\
\hline Age, years & $1.003(0.982-1.026)$ & 0.757 & - & - \\
Gender & $1.645(1.000-2.707)$ & 0.050 & $0.568(0.332-0.97)$ & 0.038 \\
Hb level & $1.066(0.958-1.187)$ & 0.243 & - & - \\
WBC levels & $1.000(1.000-1.000)$ & 0.007 & & - \\
Plt level & $1.000(1.000-1000)$ & 0.245 & - & $<0.0001$ \\
LDH levels & $1.000(1.000-1.000)$ & 0.010 & $1.00(1.000-1.001)$ & 0.003 \\
Fibrinogen levels & $1.001(1.000-1.002)$ & 0.063 & $1.002(1.001-1.004)$ & 0.056 \\
Cytogenetic risk classification & $1.530(1.079-2.171)$ & 0.017 & $1.486(0.990-2.231)$ & - \\
CD7 positivity & $1.238(0.685-2.238)$ & 0.479 & - & - \\
CD56 positivity & $0.946(0.553-1.616)$ & 0.838 & - & - \\
CD2 positivity & $5.71(0.757-43.072)$ & 0.091 & - & - \\
CD19 positivity & $0.756(0.303-1.884)$ & 0.548 & - & $<0.0001$ \\
Tdt positivity & $1.379(0.500-3.801)$ & 0.535 & - & 0.002 \\
Bone marrow fibrosis & $2.741(1.645-4.559)$ & $<0.0001$ & $4.098(2.287-7.345)$ & $0.348(0.179-0.677)$ \\
Fungal infection & $0.846(0.495-1.446)$ & 0.540 & & \\
\hline
\end{tabular}

Hb: hemoglobin; WBC: White blood cell; LDH: Lactate dehyrdogenase; Plt: platelets; Tdt: terminal deoxynucleotidyl transferase

tors that determine the treatment after remission. ${ }^{7}$ One of the strong determinants of the outcome is the performance status. Patients with an ECOG performance status score $\geq 2$ have a poor prognosis regardless of their age. ${ }^{8}$ In the study by Bertoli et al. which included 599 patients, age and ECOG performance score were found to be effective factors on complete response and leukocyte count was found to be ineffective. ${ }^{9}, \mathrm{Hb}<10$ and $\geq 10 \mathrm{gr} / \mathrm{dL}$, and ECOG $<2$ and $\geq 2$, no difference was detected in complete response to induction chemotherapy, and disease-free and overall survival among these, exerts an effect on total survival. The fact that our study did not include any patients 65 and older, explains why we did not determine the age as a factor effective on complete response, unlike the existing literature.

The most important predictive tool related to first response to the treatment, remission time, and survival time is the standart metaphase analysis. ${ }^{10}$ Negative karyotyping reflects the biological characteristics of the leukemic clone that reveals the most important prognostic features of the patients. ${ }^{11} \mathrm{t}(8.21)$, inv(16), and $\mathrm{t}(16 ; 16)$ stand for good cytogenetic risk characteristics. ${ }^{7}$ In systemic reviews and meta-analyses, it was found that FLT3-ITD mutation is associated with poor prognosis, whereas NPMI1 and CEPBA mutations are associated with good prognosis. ${ }^{12}$ In the study by Gangatharan et al., karyotype analyses of 132 of 987 patients could not be obtained, 282 of analyzed patients had normal karyotype..$^{13}$ In the study by Schnittger et al., NPM1 mutation was detected in 212 of 401 AML patients $(52.9 \%) .{ }^{14}$ In the study by Gale et al., FLT3 mutation was detected in 354 of 1425 patients $(26 \%)$ and NPM1 mutation was detected in 503 patients $(41 \%) .{ }^{15}$ In the study by Padilha et al., $40.8 \%$ of the cases were classified as intermediate cytogenetic risk group. ${ }^{16}$ In our study, karyotype analyses of 57 patients based on classical cytogenetics were available. Normal karyotype was observed in 36 of 57 patients and abnormal karyotype was observed in 21 patients. In our study, FLT-3-ITD mutation was detected in 8 patients $(8 \%)$, NPM1 mutation was detected in 22 patients $(22 \%), \mathrm{t}(15 ; 17)$ was detected in 17 patients $(17 \%), \mathrm{t}(8 ; 21)$ was detected in 3 patients $(3 \%)$, and inv.16 was detected in 6 patients $(6 \%)$. Out of 96 patients, 35 (36\%) were in favorable cy- 
togenetic risk group, 47 (49\%) were in intermediate cytogenetic risk group, 14 (15\%) were in poorrisk cytogenetic group in our study. The ratios were similar to the literature.

In the study by European Leukemia Network, when the overall survival and disease-free survival times of favorable cytogenetic risk group and other cytogenetic risk groups, and poor cytogenetic risk group and other cytogenetic risk groups were compared, the difference was statistically significant. ${ }^{17}$ In the study by Gangatharan et al., overall survival in the patient group who were under intense treatment was longer in favorable cytogenetic risk group compared to poor cytogenetic risk group. ${ }^{13}$ In our study, overall survival was statistically significantly longer in favorable cytogenetic risk group compared to the poor cytogenetic risk group, which is consistent with the literature.

Induction chemotherapy must preferentially begin as soon as possible upon completing diagnostic procedures. According to retrospective data, if there are more than 5 days between diagnosis and treatment, treatment outcome is negatively affected. ${ }^{18}$ In the study by Bertoli et al., median time of starting the treatment from the day of diagnosis was determined to be 8 days (4-16) and this duration, was not found to be an effective factor on overall survival time, response rate and premature death. ${ }^{9}$ In our study, patients started receiving induction chemotherapy after a median of 9 days (1-38) from the diagnosis. We, likewise, could not identify any positive effects of starting the treatment early on overall survival.

Presence of CD56 in blastic cells affects total remission duration and survival in AML. Presence of CD56 in blasts is considered as a poor prognosis risk group in APML. ${ }^{19}$ Immunophenotypic markers that lead to undesirable predictive results in various studies include CD7, CD19, CD11b, CD13, CD14, CD33, CD34, CD56, and Tdt. ${ }^{20}$ In the study by Raspadori et al., being CD56 (+) was identified as an independent prognostic factor on complete response. No clear correlation was detected between CD56 expression and CD34 and CD7 expression. ${ }^{19}$ In our study, CD56 positivity had no prognostic effect on complete response. No difference was detected in terms of CD34, CD7, karyotype, cytogenetic classification and complete remission between CD56 positive and CD56 negative groups. Unlike other studies, CD56 positivity was not identified as an effective factor on survival in our study. On the contrary, although not statistically different, CD56 (+) patients lived longer. Although the number of Tdt (+) patients was small, being $\mathrm{Tdt}(+)$ was found to be associated with poor prognosis.

Incidence of invasive fungal infection varies between $2 \%$ to $49 \%$ with a mortality rate upto $60 \%$ in acute leukemia and other hematologic malignancies. ${ }^{21}$ In patients diagnosed with IFI, mortality after 3 months was $28-42 \%$ in invasive aspergillosis and $23-40 \%$ in invasive candidiasis. ${ }^{22}$ In a study by Michallet et al., invasive fungal pneumonia infection was detected in 58 of a total of 216 patients (26.8\%) Invasive fungal pneumonia incidence was higher after induction chemotherapy. Mortality rate was significantly higher in the group with invasive fungal pneumonia. ${ }^{6}$ In the study by Tang et al., IFI incidence was $34.6 \%$ at the stage of induction chemotherapy. Presence of IFI at the time of induction is considered as an independent predictor of poor survival. In $75.4 \%$ of the patients with IFI, lower respiratory tract was the infected area. ${ }^{23}$ In our study, posaconazole was prescribed as a prophylactic antifungal treatment to $77 \%$ of the patients. Lung was the most frequently infected area by fungal infection (69\%). Fungal infection occured most frequently during the induction chemotherapy and had no effect on overall survival of our patients. IFI incidence at the time of remission induction was similar to the literature but overall IFI incidence was significantly higher than reported in the literature. This may arise from the envorinmental issues.

Many factors that affect overall survival were detected in patients with AML. In the study performed by Röllig et al. which included 909 patients, multivariable cox regression analysis revealed that cytogenetic risk group, presence of NPM1-FLT3 mutation, state of CD34 expression, age, leukocyte count and LDH value were independent risk factors that affect prognosis. ${ }^{24}$ Serefhanoglu et al. showed that age, ECOG performance status and diagnosis group were the factors that affect complete response and overall survival. ${ }^{25}$ In a study performed 
by Djunic et al., cox regression analysis showed that advanced age ( $>65)$, leukocytosis, LDH level and high stem cell transplant comorbidity index were important determinants of poor overall survival. ${ }^{26}$ In the study by Chen et al., 5 independent poor prognostic factors were detected in cox analysis. These were ECOG performance score $\geq 2$, /L, two-fold or higher increase in LDH value, and presence of comorbidities. ${ }^{27}$ Also, rebound thrombocytosis following induction chemotherapy is an independent predictor of a good prognosis in AML patients attaining first CR. ${ }^{28}$ In our study, those who achieved $\mathrm{CR}$ after induction therapy, those who did not have fibrosis in their bone marrow biopsy, those who had Auer body in their bone marrow aspirates, and those who were classified as having favorable cytogenetic risk had statistically significantly longer overall survival time, but ECOG performance score was not found to be a prognostic factor. In addition, in our AML patients rebound thrombocytosis following induction chemotherapy was not found to be a prognostic factor either. In stepwise cox regression analysis, gender, LDH and fibrinogen levels, cytogenetic risk classification, presence of fibrosis in bone marrow, presence of fungal infection were the factors figured out to a have an effect on mortality. Unlike the literature, the presence of bone marrow fibrosis and IFI were the most significant independent prognostic factors on mortality in our study.

There are potential limitations to our study. We have conducted a retrospective study on the clinical and cytogenetic characteristics of AML patients.

\section{Conclusion}

Complete response to induction chemotherapy, absence of fibrosis in bone marrow biopsy, presence of Auer body in bone marrow aspirations, being classified in favorable cytogenetic risk groups, and having a leukocyte count $<100000 / \mathrm{mm}^{3}$ are the most important prognostic factors that effect overall survival in patients diagnosed with AML. Immunophenotypic markers CD56, CD7, and/or CD19 do not affect the prognosis in AML, presence of Tdt, however, is associated with poor prognosis.
Gender, LDH, fibrinogen, cytogenetic risk classification, presence of fibrosis in bone marrow and presence of fungal infection are independent prognostic factors that effect mortality in patients with AML.

Approval of the local ethics committee was obtained for this study (Eskisehir Osmangazi University ethics committee, date; 15.12.2014, research number; 80558721/312).

\section{REFERENCES}

1. Jemal, A, Siegel R, Ward E, et al. Cancer statistics, 2009. CA Cancer J Clin 59: 225-249, 2009.

2. Deschler B, Lübbert M. Acute myeloid leukemia: epidemiology and etiology. Cancer 107: 2099-2107, 2006.

3. Campo E, Swerdlow SH, Harris NL, et al. The 2008 WHO classification of lymphoid neoplasms and beyond: evolving concepts and practical applications. Blood 117: 5019-5032, 2011.

4. Smith M, Barnett M, Bassan R, et al. Adult acute myeloid leukaemia. Crit Rev Oncol Hematol 50: 197-222, 2004.

5. Hoffman R, Benz EJ, Shattil SJ, et al. Hematology: Basic principles and practice. Chapter 60: Clinical manifestations of acute myeloid Leukemia. 5th edition. Philadelphia, Churcill Livingstone Elsevier, 2009: 1071-1097.

6. Michallet $\mathrm{M}$, Benet $\mathrm{T}$, Sobh $\mathrm{M}$, et al. Invasive aspergillosis: an important risk factor on the short- and long-term survival of acute myeloid leukemia (AML) patients. Eur J Clin Microbiol Infect Dis 31: 991-997, 2012.

7. Liersch R, Müller-Tidow C, Berdel WE, Krug U. Prognostic factors for acute myeloid leukaemia in adults-biological significance and clinical use. Br J Haematol 165: 17-38, 2014.

8. Appelbaum FR, Gundacker H, Head DR, et al. Age and acute myeloid leukemia. Blood 107: 3481-3485, 2006.

9. Bertoli S, Bérard E, Huguet F, et al. Time from diagnosis to intensive chemotherapy initiation does not adversely impact the outcome of patients with acute myeloid leukemia. Blood 121: 2618-2626, 2013.

10. Grimwade D, Hills RK, Moorman AV, at al. National Cancer Research Institute Adult Leukaemia Working Group. Refinement of cytogenetic classification in acute myeloid leukemia: determination of prognostic significance of rare recurring chromosomal abnormalities among 5876 younger adult patients treated in the United Kingdom Medical Research Council trials. Blood 116: 354-365, 2010.

11. Medeiros BC, Othus M, Estey EH, et al. Unsuccessful diagnostic cytogenetic analysis is a poor prognostic feature in acute myeloid leukaemia. $\mathrm{Br} J$ Haematol 164: 245-250, 2014. 
12. Port $M$, Böttcher $M$, Thol $F$, et al. Prognostic significance of FLT3 internal tandem duplication, nucleophosmin 1, and CEBPA gene mutations for acute myeloid leukemia patients with normal karyotype and younger than 60 years: a systematic review and meta-analysis. Ann Hematol 93: 1279-1286, 2014.

13. Gangatharan SA, Grove CS, P'ng S, et al. Acute myeloid leukemia in Western Australia 1991-2005: aretrospective population-based study of 898 patients regarding epidemiology, cytogenetics, treatment and outcome. Intern Med J 43: 903-911, 2013.

14. Schnittger S, Schoch C, Kern W, et al. Nucleophosmin gene mutations are predictors of favorable prognosis in acute myelogenous leukemia with a normal karyotype. Blood 106: 3733-3739, 2005.

15. Gale RE, Green C, Allen C, et al. Medical Research Council Adult Leukaemia Working Party. The impact of FLT3 internal tandem duplication mutant level, number, size and interaction with NMP1 mutations in a large cohort of young adult patients with acute myeloid leukemia. Blood 111: 2776-2784, 2008.

16. Padilha SL, Souza EJ, Matos MC, Domino NR. Acute myeloid leukemia: survival analysis of patients at university hospital of Parana. Rev Bras Hematol Hemoter 37: 21-27, 2015.

17. Alpermann T, Kern W, Schnittger S, et al. Evaluation of the proposed reporting system of the European LeukemiaNet and recommendations for prognosis of acute myeloid leukemia. Leuk Res 37: 197-200, 2013.

18. Sekeres MA, Elson P, Kalaycio ME, et al. Time from diagnosis to treatment initiation predicts survival in younger, but not older, acute myeloid leukemia patients. Blood 113: 28-36, 2009.

19. Raspadori D, Damiani D, Lenoci M, et al. CD56 antigenic expression in acute myeloid leukemia identifies patients with poor clinical prognosis. Leukemia 15: 1161-1164, 2001.

20. Webber BA, Cushing MM, Li S. Prognostic signifiance of flow cytometric immunophenotyping in acute myeloid leukemia. Int J Clin Exp Pathol 1: 124-133, 2008.

21. Neofytos D, Lu K, Hatfield-Seung A, et al. Epidemiology, outcomes and risk factors of invasive fungal infections in adult patients with acute myelogenous leukemia after induction chemotherapy. Diagn Microbiol Infect Dis 75: 144-149, 2013.

22. Even C, Bastuji-Garin S, Hicheri Y, et al. Impact of invasive fungal disease on the chemotherapy schedule and eventfree survival in acute leukemia patients who survived fungal disease: a case-control study. Haematologica 96: 337-341, 2011.

23. Tang JL, Kung HC, Lei WC, et al. High incidences of invasive fungal infections in acute myeloid leukemia patients receiving induction chemotherapy without systemic antifungal prophylaxis: a prospective observational study in Taiwan. PLos One 2015;10(6):e01248410. doi: 10.1371/journal.pone.0128410. eCollection 2015.
24. Röllig C, Thiede C, Gramatzki M, et al. A novel prognostic model in elderly patients with acute myeloid leukemia: results of 909 patients entered into the prospective AML96 trial. Blood 116: 971-978, 2010.

25. Serefhanoglu S, Büyükasik Y, Aksu S, et al. Disease characteristics and factors influencing treatment response in newly diagnosed acute myeloblastic leukema patients: a single center experience. J Ist Faculty Med 73:3, 2010.

26. Djunic I, Virijevic M, Novkovic A, et al. Comorbidity as a risk factor for overall survival and decision criteria for intensity of chemotherapy in elderly patients with acute myeloid leukemia. Med Oncol 29: 1077-1081, 2012.

27. Chen CC, Yang CF, Yang MH, et al. Pretreatment prognostic factors and treatment outcome in elderly patients with de nova acute myeloid leukemia. Ann Oncol 16: 1366-1373, 2005.

28. Malkan UY, Gunes G, Isik A, et al. Rebound thrombocytosis following induction chemotherapy is an independent predictor of a good prognosis in acute myeloid leukemia patients attaining first complete remission. Acta Haematol 134: 32-37, 2015.

\section{Correspondence:}

Dr. Hava ÜSKÜDAR TEKE

Eskisehir Osmangazi Üniversitesi Tip Fakültesi

Hematoloji Anabilim Dali

26480 Odunpazari

ESKISEHIR / TURKEY

Tel: (+90-222) 2392979 / 3854

e-mail: havaus@yahoo.com 